\title{
Evaluation of an English preparatory program at a Turkish foundation university
}

\author{
Ilknur Bayram $^{\text {a }}$ (D), Özlem Canaran ${ }^{b *}$ (iD \\ ${ }^{a}$ Ted University, Ankara, Turkey \\ ${ }^{b}$ University of Turkish Aeronautical Association, Ankara, Turkey
}

APA Citation:

Bayram, İ. \& Canaran, Ö. (2019). Evaluation of an English preparatory program at a Turkish foundation university. Journal of Language and Linguistic Studies, 15(1), 48-69.

Submission Date:07/08/2018

Acceptance Date:21/11/18

\begin{abstract}
This mixed-methods study aims to evaluate the English Preparatory Program (EPP) offered at the Department of Foreign Languages (DFL) at an English-medium foundation university in Turkey during 2017-18 academic year to discover the strengths and weaknesses of the program. Participants of the study were 241 students and 26 teachers. The data were collected from the "Program Evaluation Survey" designed by the researchers and focus group meetings with students and teachers. The results revealed that the strengths of the EPP included homework assignments, exams and the program while the extracurricular activities and online programs were found to be the main weaknesses of the EPP. It was also found that student and teacher perceptions of the EPP showed statistically significant difference. Finally, students and teachers suggested some improvements in terms of the pacing of the program, course books and supplementary booklets, number of the portfolio assignments and the picture description part in the Speaking Exam. It is hoped that the findings of the study will contribute to the improvement of the existing program and lead to better learning opportunities for students in the coming years
\end{abstract}

(C) 2019 JLLS and the Authors - Published by JLLS.

Keywords: Program evaluation; English preparatory program; student and teacher perspectives

\section{Introduction}

Learning English is becoming more and more important in Turkey which seeks to compete with the developed countries in economic and technological terms. Therefore, efforts are being made to teach it more effectively as a foreign language from primary to university education. However, the Turkey National Needs Assessment report by TEPAV (2013) state that although Turkish students receive more than 1000 hours of instruction between Grade 4 and 12, their level of English is still rudimentary and they fail to communicate in English. It is argued that students do not seem to be motivated to learn and communicate in English mostly due to the fact that their English knowledge does not contribute to their scores in university entrance exams (TEPAV, 2015). In the long run, students' lack of motivation to

\footnotetext{
${ }^{*}$ Corresponding author. Tel.: +90.312. $3847352 / 150$

E-mail address: ocanaran@thk.edu.tr

${ }^{* *}$ This paper has been presented at the $13^{\text {th }}$ METU International ELT Convention: Teaching beyond Boundaries, Ankara, Turkey.
} 
speak in English inevitably affects the EPPs delivered by the departments of foreign languages at universities.

English is the language most widely used as lingua franca among non-native speakers (TEPAV, 2013, p.29). In addition, as suggested by Flowerdew and Peacock (2001), it is a major communication tool at tertiary education and it is the language of research in many different fields. As a result of this and the internalization in higher education, the number of English-medium universities has increased around the world (Kirkpatrick, 2011) and the same is also true for Turkey. Most foundation and state universities in Turkey now offer one-year intensive EPPs to their students so that they will be equipped with necessary skills and abilities helping them communicate in English in general and academic settings. A great majority of the students who register for universities display low proficiency levels in English, and they start EPPs from beginner or elementary levels. This poses a challenge not only for students but also for teachers. It is challenging for students who - in a limited amount of time- need to be able to read, write, speak and listen in English to succeed in their departmental courses, and it is also challenging for teachers who -as curriculum developers- have to design their language curriculum in such a way that it can provide support for students with limited exposure to English so that they can pursue their academic studies in their undergraduate courses. Having a good quality curriculum is one of the key factors in achieving this ultimate aim, which can be fulfilled with ongoing program evaluation and improvement.

As is known, successful program development cannot occur without evaluation (Sanders \& Sullins, 2006, p.1). However, it is apparent that when EPPs are considered, most of our time and efforts are concentrated around designing or teaching the curriculum, rather than evaluating it (İnal \& Aksoy, 2014). As such is the case, research about curriculum evaluation that aims to identify the strengths and weaknesses of EPPs becomes even more important.

Program is defined as "any organized educational activity offered on a continuing basis" by Weir and Roberts (1994, p.3). Once implemented in schools, educational programs receive praise and criticism from many stakeholders such as teachers, students, program coordinators, administrators and academicians. Program evaluation enables such stakeholders to systematically gather data about their school's program and take subsequent actions based on the collected data (Owen, 2007). Royse, Thyer and Padgett (2010) highlight that those who attempt to evaluate a program seek to decide whether the program is functioning well or not. To determine the quality of a program and decide how to improve it, some sort of program evaluation should be conducted by the school staff or someone outside the school context. Program evaluation can be formative or summative. In formative program evaluations conducted while the program is ongoing, the purpose is to "gather feedback on aspects of the program that are undergoing review or possible revision" (Sanders \& Sullins, 2006, p.9). Summative evaluation, however, is conducted at the end of a program and "is concerned with determining the effectiveness of a program, its efficiency, and to some extent with its acceptability" (Richards, 2001, p.292). This program evaluation study was conducted by the researchers who were working as teachers at the DFL, thus making the evaluation formative in nature.

\subsection{Literature review}

Brown suggests that no curriculum should be considered complete without some form of program evaluation (2007). Taking this fact into account, several evaluation studies have been conducted in a variety of preparatory programs of Turkish universities.

In a recent study, Çelik-Yazıcı and Kahyalar (2018) explored how first year students enrolled in the faculty of economics and administrative sciences perceived the EPP at Çukurova University in terms of its content, teaching-learning processes and assessment procedures. Data were gathered through a 
questionnaire designed by researchers. Findings of the study showed that students found the program effective; however, they suggested some modifications as well so that the curriculum would better serve their needs. i.e. integration of more academic content and speaking lessons into the program and designing activities that will promote more student participation.

In a similar study, Akpur (2017) aimed to evaluate the EPP at Yıldız Teknik University through students' views by conducting a questionnaire. Based on data analysis, it was found out that the curriculum had some weaknesses. For instance, students' level of motivation to learn English was low; the curriculum did not provide the students with enough input in terms of listening and speaking skills; the duration of the program was not long enough to learn English efficiently. But, on the other hand, students found the curriculum to be effective in terms of its contribution to their reading and writing skills, its assessment procedures and the content of the materials studied throughout the year.

Özdoruk-Höke (2016) conducted a program evaluation study at the foreign languages department of Yıldırım Beyazit University based on the views of students, instructors and curriculum and testing office coordinators. She collected the views of the stakeholders through not only questionnaires but also interviews with instructors and curriculum and testing office coordinators. Findings revealed that the curriculum was found to be effective in terms of the physical conditions provided to the students, the availability of the Independent Learning Center, its resources and teaching staff and portfolio work. However, similar to Çelik-Yazıcı and Kahyalar (2018), Özdoruk-Höke (2016) suggested that the curriculum needs to be improved to better support students in their departmental courses.

In her study, Arap (2016) researched how students and teachers from four different state universities perceived the curriculum of the English preparatory schools and whether there were any significant differences between the way students and teachers perceived it. Both qualitative and quantitative data were gathered throughout the study from 1117 students and 218 teachers. Findings revealed that the curriculum partially met the needs and expectations of the students and teachers. It was also found out that students' perceptions regarding the curriculum were less positive compared to the perceptions of the teachers.

Öner and Mede (2015) investigated the perceptions of students', instructors, level coordinators and program administrators regarding an A1 level EPP designed specifically for repeat students at a foundation university in İstanbul. Data were gathered through a questionnaire administered to students and semi-structured interviews held with all the participants. Findings demonstrated that the program was perceived to be effective in general. However, all stakeholders thought more importance must be given to improving the speaking skills of the students, and the materials designed to develop their speaking skills needed to be revised to encourage them to speak in English through discussions, games and role plays. It was also indicated that there should be more time to cover the curriculum in more detail.

Inal and Aksoy (2014) analyzed the effectiveness of the English preparatory curriculum at Çankaya University using Bloom's program evaluation model. Data was gathered through questionnaires administered to 260 freshman students and 34 teachers. Findings of the study indicated that students and teachers seemed to be content with the program in a general sense. However, students and teachers were of the opinion that the learning outcomes of the curriculum did not match the requirements at their departments and the content covered in the curriculum did not have themes or topics related with students' departmental courses. Students also thought courses did not focus on speaking as much as they should, and they emphasized the need for more activities to stimulate speaking. It was also noted that teachers complained about the intensity of the curriculum, the crowdedness of the classrooms and the lack of alternative assessment carried out in the curriculum. 
Coşkun (2013) aimed to evaluate the EPP at a Turkish state university in terms of its effectiveness in relation to course materials, teaching learning processes and assessment components. A total of 381 students and 22 teachers took part in the study. Students responded to the questionnaire designed by the researcher, while the teachers participated in interviews. Based on the results, it was maintained that course materials were sufficient except the ones designed for speaking. Teachers, on the other hand, thought that materials were not designed to suit their students' needs, and they fell short of preparing their students for their departments. Concerns raised by teachers regarding the teaching-learning process was about the implementation of the modular system and the intensity of the weekly teaching hours. Assessment dimension of the program was found to be effective by students. They, on the other hand, complained about the abundance of quizzes and the online platform.

Based on the literature review regarding the evaluation of the EPPs at Turkish universities, it can be concluded that most studies tend to focus on student and teacher perceptions concerning curriculum effectiveness. Although some studies incorporate interviews as data collection tools, data about students' and teachers' perceptions are mainly gathered through questionnaires. Findings of the studies highlight that stakeholders seem to be fairly satisfied with the way the curriculum is designed to improve the English level of students. However, there is widespread dissatisfaction among stakeholders with the way the speaking skill is currently addressed. In addition, they express concerns about how and to what extent the curriculum prepares the students to pursue their academic studies at their departments.

\subsection{Research questions}

In light of the current literature, the study aimed to evaluate the EPP of a foundation university from its students' and teachers' perspective. To this end, the study sought answers to the following research questions:

1. What are the strengths and weaknesses of the EPP as perceived by students and teachers?

2. Is there a significant difference between students and teachers' perceptions of the EPP?

3. What are the students' and teachers' suggestions to improve the EPP?

\section{Method}

\subsection{Research Design}

To provide an accurate picture of a given state of affairs as fully and carefully as possible (Fraenkel, Wallen \& Hyun, 2012, p.15) and to gain a better understanding of the research questions (Creswell \& Plano Clark, 2011), the study was designed as a mixed-method research, using both quantitative and qualitative data. In the first phase of the study, quantitative data were collected through a program evaluation survey designed by the researchers and in the second phase, focus group meetings were held with the teachers and students. In the last phase, the results from both quantitative and qualitative data were converged with an aim to explain the survey data thoroughly.

\subsection{Research Context}

This program evaluation study was conducted at the DFL of a foundation university in Turkey. The EPP which was evaluated in this study is designed to help university students communicate in English effectively both in real life and academic contexts. Courses in the program which last for 33 weeks in total are offered to beginner, elementary and pre-intermediate students, focusing on all language skills and ranging from 20 to 30 hours a week. Students are required to attend $90 \%$ of all courses and expected 
to actively participate in them. Language skills are taught with an integrated approach by using a course book that balances general and academic English. Apart from the course book, students use a supplementary booklet to provide them with more choices regarding language use and skills. Students are assigned homework from an online learning management system provided together with their course books, and they also have to complete online assignments from another online system that is designed to help them reinforce the vocabulary they learn in their courses by watching short videos aligned with their English level.

Outside their class hours, EPP offers its students the chance to use English in a variety of real-life situations through extra-curricular activities. In these 30-minute-long activities, the students are encouraged to read, listen, speak and write in English in a casual atmosphere at least two times a week.

As far as the assessment is concerned, EPP combines traditional assessment such as quizzes and midterms with performance assessment. During the 33-week academic year, students take six quizzes and midterms, and three writing and speaking exams. As part of performance assessment, they are required to keep a writing and speaking portfolio, do presentations, prepare class magazines and shoot episodes to create their own TV series.

\subsection{Sample / Participants}

At the time the study was conducted, there were 281 students enrolled in the program. 40 of the students joined the piloting phase of the program evaluation survey, thus reducing the number of the students who took part in the study to 241. The gender of the students is presented in Table 1.

Table 1. Students' Genders

\begin{tabular}{ccc}
\hline Gender & $\mathrm{N}$ & $\%$ \\
\hline Male & 157 & 61.1 \\
Female & 84 & 34.9 \\
\hline
\end{tabular}

As presented in Table 1, the majority of the students who took the survey were male $(61.1 \%)$, and $34.9 \%$ of them were female. Table 2 illustrates the language proficiency levels of students taking part in the study.

Table 2. Students' Levels

\begin{tabular}{ccc}
\hline Level & $\mathrm{N}$ & $\%$ \\
\hline Beginner & 199 & 82.6 \\
Elementary & 30 & 12.4 \\
Pre-Intermediate & 12 & 5.0 \\
\hline
\end{tabular}

As illustrated in Table 2, $82.6 \%$ of the students were beginner level students $(N=199)$, while $12.4 \%$ of them were elementary level $(N=30)$. Only $5 \%$ of the students $(N=12)$ displayed pre-intermediate level of English proficiency.

At the time the study was conducted, the DFL had 30 teachers implementing the program who taught 20 hours a week. Since 4 of those teachers participated in the piloting of the program evaluation survey, a total of 26 teachers took part in the study. Table 3 presents information about the gender of the teachers. 
Table 3. Teachers' Genders

\begin{tabular}{ccc}
\hline Gender & $\mathrm{N}$ & $\%$ \\
\hline Male & 7 & 26.9 \\
Female & 19 & 73.1 \\
\hline
\end{tabular}

As can be seen from Table 3 , teachers were mostly females (65.1\%), while the remaining were males $(34.9 \%)$. Table 4 compares the teaching experiences of the participant teachers.

Table 4. Teachers' Teaching Experiences

\begin{tabular}{ccc}
\hline Teaching Experience & $\mathrm{N}$ & $\%$ \\
\hline $1-3$ & 9 & 34.6 \\
$4-6$ & 11 & 42.3 \\
$7-11$ & 6 & 23.1 \\
\hline
\end{tabular}

As illustrated in Table 4, 11 teachers (42.3\%) had a teaching experience of 4-6 years, which is followed by teachers with a teaching experience of 1-3 years (34.6\%) and 7-11 years $(23.1 \%)$.

\subsection{Data Collection}

Within the scope of this study, data were gathered through a program evaluation survey and focus group meetings. Program evaluation survey which included 5-point Likert-type items was prepared by the researchers and piloted with 40 students. The survey was found to be reliable with a Cronbach's alpha coefficient value of .93 and administered to 241 students and 26 teachers. Survey data were entered into SPSS 22 and analyzed using descriptive statistics to calculate the mean scores and standard deviations for each item on the questionnaire. To analyze the second research question, independent samples t-test was conducted to see whether the participants' perceptions of the EPP showed any statistically significant difference.

In an attempt to support the quantitative data, focus group interviews were carried out with 24 students and 26 teachers. Qualitative data were analyzed through content analysis by doing 'open coding' (Strauss \& Corbin, 1998). To achieve this, the interviews were, initially, transcribed by the researchers and the data were coded for key phrases or expressions. Then, the data were categorized according to the common ideas. The emerging categories were translated into English by the researchers as the focus group meetings with students were held in Turkish as per their preference. The researchers coded the data separately and came together to discuss the categories each of them identified and agreed on. In the end, several categories emerged from the students' and teachers' responses to open-ended questions addressed during the meetings.

\section{Results}

In this section, findings from the quantitative and qualitative data are presented respectively in two parts. In the first part, participants' responses to the questionnaire are displayed in tables reporting the descriptive statistics for each dimension of the EPP: 1) program 2) course books and supplementary booklets 3) online programs 4) extracurricular activities 5) exams 6) performance assessment 7) homework. Then, the findings from the independent samples t-test results are given to show whether the participants' views of the EPP revealed any statistically significant difference. In the second part, 
the findings from the focus group meetings are provided to present students' and teachers' suggestions to improve the EPP.

\subsection{Findings from Quantitative Data}

Primarily, the overall mean scores for each dimension of the EPP by students and teachers are illustrated in Table 5:

Table 5. Students' and teachers' perceptions of the EPP

\begin{tabular}{cccc}
\hline Dimension & Participant & Mean & SD \\
\hline Program & Student & 3.73 & 0.58 \\
& Teacher & 4.05 & 0.32 \\
Course books \& Supp. booklets & Student & 3.46 & 0.72 \\
Online Programs & Teacher & 3.91 & 0.34 \\
& Student & 2.69 & 1.45 \\
Extracurricular Activities & Teacher & 3.70 & 0.73 \\
& Student & 1.89 & 1.75 \\
Exams & Teacher & 3.60 & 1.20 \\
& Student & 3.75 & 0.68 \\
Performance Assessment & Teacher & 4.18 & 0.40 \\
& Student & 3.68 & 0.80 \\
Homework & Teacher & 4.00 & 0.48 \\
& Student & 3.78 & 0.72 \\
& Teacher & 3.93 & 0.54 \\
\hline
\end{tabular}

As presented in Table 5, the highest mean score belongs to the exam dimension of the EPP from the teachers' perceptions $(\mathrm{M}=4.18, \mathrm{SD}=0.40)$ while the students gave the highest mean score to the homework dimension $(\mathrm{M}=3.78, \mathrm{SD}=0.72)$. The findings also revealed that the students had negative views regarding the extracurricular activities $(\mathrm{M}=1.89, \mathrm{SD}=1.75)$ and online programs $(\mathrm{M}=2.69$, $\mathrm{SD}=1.45$ ); on the other hand, the teachers' perceptions were found at a moderate level both for online programs $(M=3.70, S D=0.73)$ and extracurricular activities $(M=3.60, S D=1.20)$. Considering the Program, Exams and Performance Assessment, the results in Table 5 indicate that most of the teachers agreed on the effectiveness of these dimensions whereas the students were found to be undecided about their effectiveness. In terms of the views regarding the course books, supplementary booklets and homework dimensions of the EPP, the results showed that students' and teachers' views were both at moderate levels for each of them with the teachers' overall mean scores higher than the students'. In the following parts, students' and teachers' perceptions of each dimension of the EPP are presented respectively.

Table 6. Items related to the participants' perceptions of the program

\begin{tabular}{cccc}
\hline Items & Participant & Mean & SD \\
\hline I think the EPP encourages students to learn English. & Student & 3.70 & 0.98 \\
& Teacher & 4.03 & 0.11 \\
I think the EPP has sufficient amount time for revision. & Student & 3.29 & 1.01 \\
& Teacher & 4.19 & 0.63 \\
I think the duration of each lesson (45 mins.) is & Student & 4.12 & 0.92 \\
sufficient. & Teacher & 4.42 & 0.50 \\
I think the length of the whole program is sufficient. & Student & 4.08 & 0.83 \\
\hline
\end{tabular}




\begin{tabular}{cccc}
\hline & Teacher & 4.30 & 0.54 \\
I think the EPP has been designed in a way that & Student & 3.57 & 0.93 \\
encourages students to actively participate in the & Teacher & 3.76 & 0.76 \\
lessons. & & & \\
I think the EPP will help students with their & Student & 3.61 & 1.03 \\
departmental courses. & Teacher & 3.61 & 0.69 \\
I think my teachers support me to learn English. & Student & 4.24 & 0.77 \\
I think I support my students to learn English. & Teacher & 4.30 & 0.47 \\
I think I am aware of the objectives of the EPP. & Student & 3.79 & 0.84 \\
I think my students are aware of the objectives of the & Teacher & 3.88 & 0.71 \\
EPP. & & & \\
\hline
\end{tabular}

As previously indicated in Table 5, the findings revealed that both students and teachers seemed to appreciate the program dimension of the EPP, with teachers' perceptions obtaining a higher mean score $(\mathrm{M}=4.03)$. More specifically, Table 6 shows that the students were found to be satisfied with the support they received from their teachers to learn English throughout the program as they gave the highest mean score to Item 7 in this part $(M=4.24, S D=0.77)$. Similarly, the teachers agreed that they provided their students with support to learn English since the mean score obtained from this item is very close to that of the students $(\mathrm{M}=4.30, \mathrm{SD}=0.47)$. As for the teachers, the highest mean score belongs to Item 3 , which is related to the duration of each lesson (45 mins.). The findings indicated that the teachers were satisfied with the length of the lessons (45 mins.) in the EPP $(\mathrm{M}=4.42, \mathrm{SD}=0.50)$. On the other hand, the students gave the lowest mean score to Item 2, which might indicate that the EPP does not offer students sufficient amount of time for revision $(\mathrm{M}=3.29, \mathrm{SD}=1.01)$. Concerning the teachers' perceptions, it can be seen in Item 6 that their views on the EPP and its assistance to students with department courses remained at a moderate level $(\mathrm{M}=3.61, \mathrm{SD}=0.69)$. The second lowest mean score in this dimension was obtained from Item $5(\mathrm{M}=3.57, \mathrm{SD}=0.93)$ by the students who were found to be undecided whether the EPP encouraged them to actively participate in the lessons.

Table 7. Items related to the participants' perceptions of the course books and supplementary booklets

\begin{tabular}{cccc}
\hline Items & Participant & Mean & SD \\
\hline I think all the course books used in the EPP are & Student & 3.98 & 0.81 \\
contemporary. & Teacher & 4.26 & 0.53 \\
I think all the course books used in the EPP are & Student & 3.20 & 1.05 \\
motivating. & Teacher & 3.69 & 0.54 \\
I think all the course books used in the EPP are & Student & 3.00 & 1.21 \\
interesting. & Teacher & 3.84 & 0.46 \\
I think the units (topics) in the course books & Student & 3.56 & 0.99 \\
support each other. & Teacher & 4.07 & 0.48 \\
I think the course books encourage students to do & Student & 2.87 & 1.10 \\
$\quad$ research. & Teacher & 3.53 & 0.58 \\
I think the course books are appropriate to the & Student & 3.73 & 0.93 \\
students' level of English. & Teacher & 3.80 & 0.48 \\
I think the supplementary booklets support the & Student & 3.80 & 0.98 \\
topics in the course books. & Teacher & 4.19 & 0.74 \\
I think the supplementary booklets help students & Student & 3.53 & 0.97 \\
learn the topics that they couldn't understand in & Teacher & 3.88 & 0.76 \\
the lessons. & & & \\
\hline
\end{tabular}


When the students' and teachers' perceptions of the course books and supplementary booklets are considered, the findings in Table 7 indicate that both students and teachers agreed that the course books used in the EPP were all contemporary $(\mathrm{M}=3.98, \mathrm{SD}=0.81 ; \mathrm{M}=4.26, \mathrm{SD}=0.53)$. In addition, the teachers considered that the supplementary booklets supported the course books well $(\mathrm{M}=4.19, \mathrm{SD}=0.74)$. Similarly, the students held the view that the course books were supported by the supplementary booklets ( $\mathrm{M}=3.80, \mathrm{SD}=0.98)$. According to the findings, the students were found to disagree with Item $13(\mathrm{M}=2.87, \mathrm{SD}=1.10)$, which meant that students were of the opinion that they were not encouraged by the course books to do research. On the other hand, the teachers seemed to be unsure whether the course books motivated their students to do research $(\mathrm{M}=3.53, \mathrm{SD}=0.58)$ either. Table 7 also shows that the students generally remained undecided regarding the course books' being interesting $(\mathrm{M}=3.00$, $\mathrm{SD}=1.21)$ and motivating $(\mathrm{M}=3.20, \mathrm{SD}=1.05)$ to them. In contrast, the teachers' responses to Item 10 were found at a moderate level $(\mathrm{M}=3.69, \mathrm{SD}=0.54)$ while their responses to Item 11 indicate that the course books used in the EPP were somewhat interesting $(\mathrm{M}=3.84, \mathrm{SD}=0.46)$

Table 8. Items related to the participants' perceptions of the online programs

\begin{tabular}{cccc}
\hline Items & Participant & Mean & SD \\
\hline I think the online programs in the EPP help students & Student & 2.64 & 1.56 \\
learn English. & Teacher & 3.65 & 1.09 \\
I find NLL online program useful for revising the topics. & Student & 2.58 & 1.53 \\
& Teacher & 4.03 & 0.66 \\
I think the online vocabulary learning program helps the & Student & 2.83 & 1.60 \\
students learn the words in English. & Teacher & 3.42 & 1.27 \\
\hline
\end{tabular}

As for the participants' views on the online programs, Table 8 displays that the students' and teachers' perceptions differed on each item. While the findings for Item 17 indicate that the students did not seem to find the online programs helpful to learn English $(\mathrm{M}=2.64, \mathrm{SD}=1.56)$, the teachers' views remained at a moderate level $(\mathrm{M}=3.65, \mathrm{SD}=1.09)$. Regarding Item 18 , which was about online programs and their usefulness for revision, it was found that the students gave the lowest score to this item $(\mathrm{M}=2.58, \mathrm{SD}=1.53)$ whereas the teachers agreed that online programs were useful for revising the topics $(\mathrm{M}=4.03, \mathrm{SD}=0.66)$. The last item also shows that the students and teachers disagreed regarding the online vocabulary learning program. As can be understood from the table, the students did not think that the online vocabulary learning program helped them learn English words $(\mathrm{M}=2.83, \mathrm{SD}=1.60)$, the teachers, on the other hand, seemed to be undecided whether the online vocabulary program was helpful for students to learn English vocabulary ( $\mathrm{M}=3.42, \mathrm{SD}=1.27)$.

Table 9. Items related to the participants' perceptions of the extracurricular activities

\begin{tabular}{cccc}
\hline Items & Participant & Mean & SD \\
\hline I find Conversation Class events useful for providing the & Student & 2.12 & 1.91 \\
students with speaking practice in English. & Teacher & 3.57 & 1.39 \\
I think the More Language Time events help the students & Student & 1.93 & 1.92 \\
revise the grammar subjects. & Teacher & 3.84 & 1.25 \\
I think I Love English events encourage the students to & Student & 1.63 & 1.78 \\
speak English. & Teacher & 3.38 & 1.16 \\
\hline
\end{tabular}

In terms of the students' and teachers' perceptions of the extracurricular activities, the findings in Table 9 indicate that the students and teachers disagreed about the Conversation Class event being useful 
for speaking practice. While the mean score for item 20 was 2.12 by the students, which might mean that they did not find the Conversation Class event useful, the mean score obtained from the teachers was 3.57, which indicates that teachers neither agreed nor completely disagreed about the Conversation Class and its advantage to students. Furthermore, the students' and teachers' responses to item 21 were also not corresponding to each other. For revising the grammar topics, More Language Time as an extracurricular activity received a very low mean score from the students $(M=1.93, S D=1.92)$ while the teachers seemed almost satisfied with its assistance to students with grammar revision $(\mathrm{M}=3.84$, $\mathrm{SD}=1.25$ ). As for the last item related to the extracurricular activities dimension of the EPP, it was found that the students did not think I Love English Events encouraged them to speak English $(\mathrm{M}=1.63$, $\mathrm{SD}=1.78$ ) whereas the teachers' responses were found at a moderate level with a mean score of 3.38 .

Table 10. Items related to the participants' perceptions of the exams

\begin{tabular}{cccc}
\hline Items & Participants & Mean & SD \\
\hline I think the number of the Unit Tests in the EPP is & Student & 4.04 & 0.96 \\
sufficient. & Teacher & 4.23 & 0.58 \\
I think the Unit Tests assess all the language skills & Student & 3.63 & 0.94 \\
well. & Teacher & 4.19 & 0.69
\end{tabular}

I think the duration is sufficient for the students to respond the questions in the Unit Tests.

\begin{tabular}{|c|c|c|}
\hline Student & 3.66 & 1.09 \\
\hline Teacher & 4.26 & 0.45 \\
\hline Student & 3.85 & 0.95 \\
\hline Teacher & 4.30 & 0.61 \\
\hline Student & 3.64 & 0.93 \\
\hline Teacher & 4.15 & 0.46 \\
\hline Student & 3.55 & 1.04 \\
\hline Teacher & 4.34 & 0.45 \\
\hline Student & 3.90 & 0.96 \\
\hline Teacher & 4.30 & 0.54 \\
\hline Student & 3.70 & 0.99 \\
\hline Teacher & 4.19 & 0.56 \\
\hline Student & 3.54 & 1.15 \\
\hline Teacher & 4.23 & 0.58 \\
\hline Student & 3.67 & 1.00 \\
\hline Teacher & 4.03 & 0.72 \\
\hline Student & 3.79 & 0.87 \\
\hline Teacher & 3.84 & 0.73 \\
\hline Student & 4.05 & 0.90 \\
\hline Teacher & 4.42 & 0.64 \\
\hline Student & 3.81 & 0.96 \\
\hline Teacher & 3.92 & 0.68 \\
\hline
\end{tabular}

I think the number of the Progress Tests in the EPP is sufficient.

I think the Progress Tests assess all the language skills well.

I think the duration is sufficient for the students to respond the questions in the Progress Tests.

I think the number of the Full Tests in the EPP is sufficient.

I think the Full Tests assess all the language skills well.

I think the duration is sufficient for the students to respond the questions in the Full Tests.

I think the exams in the EPP cover the topics the have been studied in the lessons.

I think the exams in the EPP help the students learn English.

I think the immediate feedback given after the exams in the EPP contributes to the students' learning.

After the exams my teachers support me well about the subjects I need to study more.

After the exams I support my students well about the subjects they need to study more. 
As for the items related to the exams in the EPP, Table 10 illustrates that the highest mean score in this dimension was obtained from Item 34 on which both students $(\mathrm{M}=4.05, \mathrm{SD}=0.90)$ and teachers $(\mathrm{M}=4.42, \mathrm{SD}=0.64)$ were found to show agreement. It was understood from the findings that immediate feedback given by the teachers after the exams helped students learn English. Furthermore, the participants were found to hold similar views regarding the number of the Unit Tests in the EPP. As we can see in Table 10, the mean score for Item 23 was 4.04 from the students and it was 4.23 from the teachers, which indicates that the EPP offered a sufficient number of Unit Tests throughout the academic term. On the other hand, the findings of the study revealed that the students and teachers mostly disagreed about the items related to the exams. According to the results, the students and teachers disagreed about the effectiveness of the tests in assessing their language skills. When the participants were asked whether the Unit Tests could assess language skills well or not, we found that the students were generally unsure about their effectiveness $(\mathrm{M}=3.63, \mathrm{SD}=0.94)$ whereas the teachers agreed that the Unit Tests assessed language skills well. We obtained similar results regarding the Progress Tests in Item 27 as well as the Full Tests in Item 30. The mean score given to Item 27 by the students was 3.64 while it was found to be 4.15 by the teachers. This also indicates that the students remained undecided about the effectiveness of the Progress Tests to assess language skills while the teachers mostly agreed about their effectiveness. As for the Full Tests in Item 30, it was similarly found that the students' responses were at a moderate level with a mean score of 3.70, but the teachers' responses achieved a higher mean score of 4.19. As far as the duration of the tests is considered, we found that the participants had different perceptions. To illustrate, the mean score of 3.66 from students and 4.26 from teachers was obtained for Item 25 which is related to the duration of the Unit Tests, indicating that students did not totally agree with the statement while the teachers did. Similar results were received for Item 28 and Item 31 which were about the duration of the Progress Tests and Full Tests respectively. Furthermore, the mean scores given to Item 32 indicated that the students were undecided whether the exams in the EPP covered the topics that were studied in the lessons $(\mathrm{M}=3.67, \mathrm{SD}=1.00)$ whereas the teachers were found to agree with the statement $(\mathrm{M}=4.03, \mathrm{SD}=0.72)$. On the other hand, Table 10 displays that both students' and teachers' responses to Item 35 remained at a moderate level, $(\mathrm{M}=3.81$, $\mathrm{M}=3.92$ ) with that of the teachers' a little higher, pointing to the fact that teacher support to students after exams was not found sufficient by both participants of the study.

Table 11. Items related to the participants' perceptions of the performance assessment

\begin{tabular}{cccc}
\hline Items & Participant & Mean & SD \\
\hline I think the writing tasks in NLL portfolio help students & Student & 4.07 & 0.96 \\
improve their writing skills in English. & Teacher & 4.11 & 0.71 \\
I think the speaking tasks in NLL portfolio help students & Student & 3.40 & 1.20 \\
improve their speaking skills in English. & Teacher & 3.92 & 0.68 \\
I think the In Class Speaking Performance encourages & Student & 3.75 & 1.05 \\
students speak English in the lessons. & Teacher & 3.88 & 0.71 \\
I think the Presentation Task in the EPP helps students & Student & 3.48 & 1.13 \\
improve their speaking in English. & Teacher & 4.11 & 0.71 \\
\hline
\end{tabular}

Considering the items related to the participants' perceptions of the performance assessment, Table 11 displays that while the students $(\mathrm{M}=4.07, \mathrm{SD}=0.96)$ and teachers $(\mathrm{M}=4.11, \mathrm{SD}=0.71)$ mostly agreed on Item 36, it was understood from the lower mean scores of 3.40 and 3.92 for item 37 that they did not completely confirm the statement. The findings for Item 38 also revealed that both students $(M=3.75$, $\mathrm{SD}=1.05)$ and teachers $(\mathrm{M}=3.88, \mathrm{SD}=0.71)$ thought that In Class Speaking Performance encouraged students to speak English in the lessons at a moderate level. As for the last item in this dimension of the 
EPP, the students and teachers were found to hold different opinions. Regarding the Presentation Task and its assistance for improving speaking, the results showed that the students were undecided $(M=3.48$, $\mathrm{SD}=1.13)$ while the teachers had positive views $(\mathrm{M}=4.11, \mathrm{SD}=0.71)$.

Table 12. Items related to the participants' perceptions of the homework

\begin{tabular}{cccc}
\hline Items & Participant & Mean & SD \\
\hline I think the number of the assignments in the EPP is & Student & 3.83 & 0.97 \\
sufficient to revise the topics. & Teacher & 4.03 & 0.72 \\
I think the assignments given in the EPP are appropriate & Student & 3.76 & 0.90 \\
to the students' level of English. & Teacher & 3.92 & 0.62 \\
I think the assignments given in the EPP help the & Student & 3.74 & 0.87 \\
students learn English. & Teacher & 3.84 & 0.67 \\
\hline
\end{tabular}

According to the results in Table 12, the number of the assignments was sufficient for revision from the perspectives of the teachers $(\mathrm{M}=4.03, \mathrm{SD}=0.72)$ while it was not totally sufficient, though very close to that of the teachers, from the perspectives of the students $(\mathrm{M}=3.83, \mathrm{SD}=0.97)$. In terms of the appropriateness of the assignments to the students' level in Item 41, it was seen that the students $(\mathrm{M}=3.76, \mathrm{SD}=0.90)$ and the teachers $(\mathrm{M}=3.92, \mathrm{SD}=0.62)$ agreed with the statement moderately. When asked whether the assignments given in the EPP helped the students learn English, the students $(\mathrm{M}=3.74$, $\mathrm{SD}=0.87)$ and the teachers $(\mathrm{M}=3.84, \mathrm{SD}=0.67)$ seemed to be undecided about the statement.

To answer the second research question of the present study; Is there a significant difference between students' and teachers' perceptions of EPP? the participants' responses were compared using an independent samples t-test. Table 13 below displays the findings from the t-test:

Table 13. Independent sample t-test results

\begin{tabular}{ccccccc}
\hline Participants & $\mathrm{N}$ & $\mathrm{M}$ & $\mathrm{SD}$ & $\mathrm{t}$ & $\mathrm{df}$ & $\mathrm{P}$ \\
\hline Student & 241 & 3.28 & 0.63 & -7.8 & 44.56 & 0.000 \\
Teacher & 26 & 3.91 & 0.35 & & & \\
\hline
\end{tabular}

An independent samples t-test was conducted to compare the students' and teachers' perceptions of the EPP. The statistical analysis indicated that there was a significant difference between the students' perceptions $(\mathrm{M}=3.28, \mathrm{SD}=0.63)$ and the teachers' perceptions $(\mathrm{M}=3.91, \mathrm{SD}=0.35)$; $\mathrm{t}(-7.8)=44.56$, $\mathrm{p}=0.000$. These results suggest that students and teachers held different views regarding the EPP with the teachers' perceptions obtaining a higher mean score than those of the students.

\subsection{Findings from Qualitative Data}

Qualitative data were collected through focus group meetings with the aim of supporting quantitative data and reaching in-depth information about the participants' perceptions of the EPP. A group of 24 students and 26 teachers were asked questions through focus group meetings for their opinions regarding the things that were going well and the things that needed improvement in the EPP. The results indicate that students and teachers had some suggestions for improvement regarding the pacing of the weekly program, course books and supplementary booklets, speaking tasks, writing tasks and speaking exams of the EPP. 


\subsubsection{Pacing of the Weekly Program}

The students' and teachers' perceptions during the focus group meetings revealed that the weekly program in the first period continued at a normal pace while in the second period it accelerated so much that it became hard to understand and internalize the topics for students during the lessons. Due to the fast pace of the program, some students expressed that they sometimes felt as if their teachers were caring more about finishing the units on time than helping them learn what was being studied. In addition, this heavy load in the weekly program seemed to prevent the students from receiving effective feedback from their teachers. Some of the students commented on this as follows:

"The units in the program are studied too fast. Why do we have to study two units a week? When I can't understand a topic, there is no time for asking questions to our teacher and I always prefer asking questions during the class time because I don't think the office hours are effective to learn a topic." (Student 16, 17 April 2018)

"There should be more time for feedback in the program. It would be much better if we could study 1,5 units a week instead of 2 units. When the program goes too fast, I can't keep up with the speed of the teacher, then I become demotivated and stop listening to her." (Student 4, 16 April 2018)

Another point made by the students was related to the lack of opportunities for speaking practice in class. Students seemed to agree that the pacing of the weekly program after the first period hindered having conversational exercises or speaking practice in English. It was expressed that when they asked for more speaking opportunities, they were sometimes rejected by their teachers with an excuse that they would fall behind the weekly program if they spared some additional time on such exercises.

\footnotetext{
"Sometimes when we get bored in the lesson, we ask our teacher for speaking activities. However, we are generally rejected with always the same reason: we have to finish the unit as we have fallen behind the program." (Student 20, 17 April 2018)

"I am sure most of my friends will agree with me that during the first weeks of the program we were very flexible and there was sufficient time for everything like doing some speaking practice in class. But in the second term everything changed all of a sudden, we became like runners... The units are done one after another but when it comes to speaking, there is little chance for it at all." (Student 22, 17 April 2018)
}

Similarly, the teachers agreed that unlike the program in the first period, the program in the second period becomes harder for teachers to teach and students to learn. Some teachers expressed that nobody can expect learning to occur with such a fast pace and their students were also concerned about the intensiveness of the weekly program. Some of the teachers' views are provided below:

"In the first period we have a really flexible program, but in the second and third period it turns into a very intense program. For this reason, we need to consider if learning can really take place with such an intense weekly program." (Teacher 1, 27 April 2017)

"We believe that the weekly program becomes too intense and hard to keep up with as of the second period. There are too many units in one week and some of my students say that this leads them to memorization and leaves no room for practice during the lesson. It is as if we have to finish the unit and continue with the new one immediately." (Teacher 7, 27 April 2017)

To sum up, data analysis revealed that the weekly program went well in the first period although it became too fast and loaded in the second period, preventing some students from comprehending the lesson, asking questions and receiving feedback from the teacher in addition to doing more speaking practice in the class. 


\title{
3.2.2. Course books and Supplementary booklets
}

Another category that emerged from data analysis was related to the course books and supplementary booklets used in the program. Regarding the course books, the students held the view that despite being contemporary and motivating, they lacked a number of listening and reading exercises that would familiarize them with the exams. Thus, they expressed that the books needed to be supported by additional listening and reading exercises which were similar to the ones they had in the exams in terms of their content, length and difficulty. Two students stated that:

"There are a lot of reading exercises in the course books but I always get a low mark in reading exams. The problem is the question types in the exams and the exercises we do in the lessons are different. Teachers can give us some exercises that are similar to the ones we will be asked in our exams. " (Student 3, 16 April 2018)

"I think the books are modern and interesting, but some of my friends and I have a problem with listening and reading exercises in the books. They are too long and the words are too difficult to understand. We need extra materials to improve ourselves in listening and reading because the books don't help us in that sense." (Student 7, 16 April 2018)

One of the teachers agreed with the students that the students needed to be supported in the lessons with some additional listening and reading exercises which will also prepare them for the exams. She said:

\begin{abstract}
"We should have some more exercises which are similar to the exams especially for listening and vocabulary. Because we are using some good activities in the lessons, but they are not very similar to the exams, our students complaining about it too much. Thus, we are not sure about the link between the program and exams." (Teacher, 427 April 2018)
\end{abstract}

Concerning the supplementary booklets, the students' responses were found to appreciate the exercises in the booklets. It was also found that they preferred to study the supplementary booklets during the class with the teacher rather than having it as a homework assignment. Referring to the fast pace of the program again, they expressed that in the first period the weekly program was conducive to study the booklet in the class with the help of the teacher and this led to learning the subjects better. They now seemed to be dissatisfied with the fact that their teachers began to assign the supplementary booklet as homework for extra practice due to the limited amount of time in the weekly program. Below are some of the students' comments to evidence this finding:

"There are a lot of good exercises in the supplementary booklet and I really find it useful to make revision." (Student 3, 16 April 2018)

"Step-up (supplementary booklet) is very good for extra practice, but I always prefer doing it in the class to doing it as homework. Now in the second period our teacher gives it as homework and to be honest I don't do it." (Student 24, 17 April 2018)

Similarly, the teachers expressed their appreciation about the supplementary booklet which they believed to contain several useful exercises for students to help internalize the topics. Two teachers said:

"I believe reading and listening activities are really useful in the supplementary booklet." (Teacher 11, 28 April 2018)

"We like the supplementary booklet because it has a lot of activities, in fact a wide range of activities and it is good to use it in the class as it helps students a lot for their exams." (Teacher 4, 27 April 2018) 
To sum up, qualitative data analysis revealed that the students were overwhelmed with the length and difficulty of the reading and listening texts in the course books. They also thought that they should be given similar types of reading and listening questions in the exams or they should be provided with additional materials in the lessons on these skills. Furthermore, both students and teachers favored the supplementary booklet but they suggested studying it during the lesson instead of doing it as homework assignment.

\subsubsection{Speaking and Writing Tasks}

One of the components of the portfolio assessment in the EPP, writing tasks, as quantitative data analysis yielded, were found useful by students and teachers to improve their writing skills in English. On the other hand, qualitative data analysis showed that the students were worried about not receiving effective and timely feedback from the teachers due to the number of the writing tasks. Data analysis showed that some students became nervous about meeting the deadline of the tasks, which also prevented them from focusing on the quality of the assignment. Thus, they suggested that the number of the tasks should be reduced so that they could spend more time with the teachers to get feedback about their assignments to ensure higher quality. Some of the students' comments regarding the writing tasks are as follows:

"As we have a lot of writing tasks in the program, our teacher can't find time to give us feedback. We are always rushed to finish one task and start writing a new one. Sometimes I don't read what is written on the feedback form as it is too short or meaningless." (Student, 5, 16 April 2018)

"There are too many writing tasks and I can't understand the reason behind that. Why are we given a lot of tasks? I don't believe I will write better when I have more tasks. I feel many of us have become tired of trying to meet the deadline." (Student, 20, 17 April 2018)

"We have too many writing tasks and they are repetitive and similar. For example, we had a lot of e-mail tasks and we wrote it several times, which bored us much and I don't think I wrote it much better for the second task. When we get bored, we become demotivated. You should take this seriously." (Student 16, 17 April 2018)

One of the teachers expressed his concern regarding the high number of the writing tasks and giving ineffective feedback to his students as in the following comment:

"As most of my colleagues will agree quantity is high, quality is low. On feedback forms I can honestly tell that sometimes I don't even read my own feedback. Mostly it's too short since I can't find anything to write ... I really don't know what to write as feedback. Teachers get bored, students get bored, everyone is unhappy...so what's the aim of it?" (Teacher 12, 27 April 2018)

As another component of the portfolio assessment, speaking tasks in the speaking portfolio, similarly, was not without suggestions from the students. In contrast to the writing tasks, speaking tasks in the questionnaire received a moderate mean score from students regarding its effect on improving speaking skills. According to qualitative data analysis, the first issue underlined by the students was the high number of the speaking tasks given on a weekly basis. The students criticized that the tasks were assigned so frequently that they could not find sufficient time after classes to shoot their video to complete the task. Moreover, task requirements regarding the length of the video needed reconsideration as they were not able to speak English so long that they sometimes shot the video using a lot of actions and movements instead of speaking English. Some of the comments from the students are as follows:

"Actually we like speaking tasks a lot and we believe they are helpful for us to improve our speaking. But each week we have one speaking task and I think this is too much. Our classes finish at 15:30 and after this time we can't find enough time to come together as a group, prepare our speech, distribute roles and 
shoot our video. For this reason, we suggest doing them once in two weeks' time." (Student 5, 16 April 2018)

"Expecting us to speak for 2 minutes is unfair. This is too long. We sometimes have to walk, run, dance to be able to meet the expected duration of the video. 1 minute for each person is OK in my opinion." (Student 3, 16 April 2018)

Regarding the speaking tasks one of the teachers made the following comment:

"We shouldn't have speaking tasks for each unit because it is really tiring for students as some of them are really enthusiastic about them. If the number of the tasks is reduced, it might be better. Since they (students) find it too time consuming, some of them stop doing it." (Teacher 10, 27 April 2018)

Data analysis indicated that the students and teachers are concerned about the frequency of the tasks that the students were expected to complete as part of their writing and speaking portfolio. It seemed that the students could not meet the deadlines and the teachers could not offer effective feedback, which, in the end, appeared to cause dissatisfaction and demotivation for everybody. For this reason, it was suggested that having a reduced number of tasks would motivate students to do the tasks and help receiving quality feedback from the teacher.

\subsubsection{Speaking Exams}

Another issue raised by the students is concerned with the pictures they were asked to describe in the speaking part of the Proficiency Test of English. It was agreed that the pictures were sometimes very abstract or without enough descriptive figures that would assist them to generate ideas and encourage them to speak English. One student comments as follows:

"Pictures should be carefully selected. Some pictures are easy, but some pictures are too difficult to talk about. For example, in the previous exam I was given a picture with a lion sitting alone on the street. That's all! What am I supposed to talk about when there is little to describe in the picture?" (Student 18, 17 April 2018)

The teachers agreed that picture selection should be carefully made during the exam preparation since some of the pictures were easier to describe while some of them were really hard. This might sometimes lead to unfairness between the students. Moreover, the pictures should contain more figures, colors or actions so that students would be able to speak on them. One of the teachers suggested:

"For speaking exams, we should offer our students pictures which they can produce more ideas about. I believe some pictures in the exams are very easy to describe while some others are too difficult to talk about for students. The pictures should include more figures, activities. Then it may be easier for them to talk about it." (Teacher 9, 27 April 2018)

Regarding the exam dimension of the EPP, qualitative data showed that the students and teachers agreed that the picture description part in the speaking exam needed to be designed with utmost attention while choosing the pictures as some of the pictures fell short of encouraging students to speak in English without sufficient objects, figures or actions.

\section{Discussion}

The aim of this study was to evaluate the EPP offered at the Department of Foreign Languages (DFL) at an English-medium foundation university in Turkey to discover its strengths and weaknesses from student and teacher perspectives. 
The first research question sought to investigate the strengths and weaknesses of the EPP as perceived by students and teachers. The data from the questionnaire indicated that the strengths of the EPP from the students' views were homework and exam dimensions while the teachers agreed that the strengths of the EPP were exams, program and performance assessment. On the other hand, the results revealed that the extracurricular activities and online programs were the main weaknesses of the EPP both from the students' and teachers' perspectives. More specifically, when the program dimension is considered, we found that most students appreciated their teachers for supporting them to learn English. Similarly, the teachers were of the opinion that they were supporting their students sufficiently to learn English. Thus, we might conclude that the EPP succeeded in forming strong relationships and creating a supportive learning environment where students felt valued and encouraged by their teachers. As Bandura (1986) stated "many students have difficulty in school not because they are incapable of performing successfully, but because they are incapable of believing that they can perform successfully" (p.390), teachers are influential in helping their students learn as well as helping them feel they can learn. Thus, we can conclude that the EPP might have achieved building a learning environment where students were motivated and supported well by their teachers. However, to the students' view, the EPP was considered to be weak on sparing enough time for revision. This accords with the results of the qualitative data which similarly showed that the pacing of the program for the second period needed to be reset as students had hard time understanding the lesson, finding time for revision and receiving feedback from the teacher and doing speaking practice. Pacing can be defined as " the rhythm and timing of classroom activities or units, which includes the way time is allocated to each classroom component and the process of how one decides that it is the right moment to change to another activity, sub-activity, or sub-subactivity" (Goldsmith, 2009, p.33). The case study conducted by Goldsmith (2009) on pacing and time allocation indicated that with careful attention to pacing by a teacher, there will be enough time for various activities, particularly communicative, oral activities.

As regards the strengths of the course books and supplementary booklets, the students and teachers were holding similar views in terms of their being up-to-date and complementing each other. It was also understood from the interviews that the students were particularly looking for opportunities to study the supplementary booklet as an in-class activity since they found the exercises in the booklet very useful for their learning. On the other hand, the listening and reading exercises in the course books were found to be challenging for students due to their length and content. Furthermore, both students and teachers commented that such reading and listening exercises in the course books did not prepare them sufficiently for the exams.

As one of the weaknesses of the EPP, online programs, as perceived by students, seemed to be disfavored with their little contribution to learning English, revising topics and learning new vocabulary. Despite finding them useful on the questionnaire for revising the topics, the teachers were generally hesitant about the effectiveness of the online programs. However, the focus group meetings both with the students and teachers did not reveal any perceptions on the weaknesses of the online programs. The reason behind this might be attributed to the fact that the students were not in the habit of doing online homework despite being assigned by their teachers regularly. When they were asked about the reason why they did not do the online homework, some of the students came up with such excuses as having no internet connection where they resided, facing technical problems, or lack of awareness and motivation about why they needed to do them. For this reason, we might infer that the online programs received a low mean score in the questionnaire not because of their ineffectiveness but because of the students' lack of knowledge and experience with them. According to Erarslan \& Topkaya (2017), online learning can assist learners in several ways such as transforming the knowledge they receive in the classroom into language production as well as triggering positive thinking and communicative skills, enhancing motivation and adding to the student's success in the classroom. On the other hand, studies 
(Akbari, Eghtesad, \& Simons, 2012; Cinkara \& Bagceci, 2013 as cited in Eraslan \& Topkaya, 2017) indicated that students' attitudes to online programs or e-learning had an influence on the benefits they gained from e-learning as well as its effect on their success.

Very surprisingly, extracurricular activities which were expected to encourage students more to learn English with fun and joy after classes were found to receive the lowest mean score both from the students and teachers on the questionnaire. Though the teachers were generally undecided about the helpfulness of the extracurricular activities for students, almost no students agreed that Conversation Class, More Language Time and I Love English Events helped them improve either their speaking or grammar skills. As was the case with the online program, students' giving low score to the extracurricular activities might be attributed to their not attending these activities at all. When the attendance records for these events were examined, it was found that the students were not attending the courses. For this reason, we might think that the questionnaire results might not show the real case with these events. Instead, the main reason why the students did not prefer to take part in these events needs to be investigated. The importance of participation to the extracurricular activities was also stated in the study by Gardner, Roth, and Brooks-Gunn (2008) who suggested that unless students attend extracurricular activities, they cannot take the advantage of their benefits. It was underlined that the more students join extracurricular events, the more they understand their impact on them.

As far as the exam dimension is considered, the findings from the questionnaire showed that both students and teachers held positive views regarding the effectiveness of the immediate feedback given after the exams by the teacher. So, one can think that this practice is one of the strengths of the assessment dimension of the EPP and should be maintained as both students and teachers gave high scores for its contribution to learning. On the other hand, qualitative data revealed that the students and teachers were concerned about the picture description part of the speaking exam and they argued that some of the pictures, instead of encouraging students to speak, did not encourage them to generate ideas. Thus, those who are in charge of selecting pictures could be informed about the results of this study and pay more attention to selecting pictures that will help students produce ideas. Regarding assessment, Brown (2005) suggests that the reason why we are assessing students will surely affect the choice of assessment instruments. Taking Brown's suggestion into account, we should consider the rationale behind the use of the pictures in the exam and ponder whether we really want to motivate students and encourage them to speak.

Although the performance assessment received average scores from the students and high scores from the teachers on the questionnaire, qualitative data yielded that there was a problem about the number of the writing and speaking tasks. It was understood from the findings that the high number of the tasks discouraged students from doing them and teachers from giving feedback. Both participants agreed that the quality of the assignments and motivation of the students reduced due to the frequency of the assignments. In addition, the length of the speaking video was criticized by the students for being too long and students suggested a reduction in the length and number of the videos. When the importance of portfolio keeping for developing language skills is considered, we can say that these criticisms should be taken into account for the next academic year so that the students would be encouraged to keep writing and speaking with teachers giving more effective feedback.

Regarding the homework dimension, we can say that the teachers and students were happy about the number of the assignments for revision despite being undecided about their appropriateness to the students' level and help in learning English. Although this was not particularly expressed as a problem during the focus group meetings, it is important to investigate the reasons why the participants did not agree with these two issues. Thus, there might be a need for a more specific research on the individual dimensions of the program in order to find out the main reasons about the students' and teachers' concerns. 
As for the second research question of the study, it was investigated whether the students' and teachers' perceptions regarding the EPP showed any statistical difference. The findings revealed that the students' and teachers' perceptions were significantly different from each other with the teachers' overall mean score being higher than that of the students. This finding is in agreement with the results obtained by Arap (2016) who found that students' and teachers' perceptions of the curriculum of the English preparatory schools showed difference and students held less positive views than teachers. This might be attributed to the teachers' active involvement in the preparation, implementation and evaluation of the EPP. In addition, as the curriculum and testing office coordinators were holding regular meetings with the teachers throughout the academic year to explain and discuss the rationale of the practices regarding the EPP, we can infer that the teachers' awareness and knowledge about the program might have led them to hold more positive views than students and believe in the effectiveness of the practices. Besides awareness and knowledge, experience of the teachers who have been working in the institution for more than three years might be a determining factor as well in their responses. Since these teachers might have confidence in the EPP depending on their previous experiences, they might have given more positive responses. On the other hand, students' with less awareness about the objectives of the EPP and with a lot of concerns about their end-of-the-term score to pass the EPP might have been more skeptical about the EPP. For this reason, students could be informed about the objectives of the program and be made aware of the rationale behind the practices through regular meetings held by the teachers, program coordinators and administrators. In these meetings, feedback from students should also be gathered so that an immediate action could be taken on the way for the issues that might not be going well.

The last research question was concerned about the students' and teachers' suggestions for the improvement of the EPP. The qualitative data gathered through focus group meetings indicated that there were a number of points to take into consideration. First of all, students and teachers suggested slowing down the pace of the weekly program in the second term as it was found to be too fast for the students to keep up with and teachers to cover the subjects thoroughly. For this reason, the program coordinators might consider reducing the load of the program for the next academic year as it appeared that some of the students were not benefitting from the lessons effectively due to the weekly load. Some students suggested studying 1.5 units a week instead of 2 units, which they believed could spare more time for feedback, revision and speaking practice in the class. Having more and efficient time for speaking practice was also obtained from the program evaluation surveys conducted by Öner and Mede (2015), İnal and Aksoy (2014) and Coşkun (2013). This might indicate that the amount of time and practice spared to improve speaking skills of students in English preparatory programs need to be reconsidered by teachers and curriculum designers.

Another suggestion from the teachers and students of the EPP was related to providing students with more reading and listening exercises that would contain similar types of questions that were asked in the exams. This suggestion could be taken into consideration as there was a consensus between the participants regarding the need for more reading and listening exercise to support the course books. The third suggestion was about reducing the number of the writing and speaking tasks in the performance assessment. The students and teachers criticized the number of the tasks expressing that this led to giving up learning and quality of the assignments. In a limited amount of time with many tasks to be completed, the students felt rushed and they received low quality feedback from the teacher to improve the task for the next time. The program coordinators might question whether it is the quality or quantity that really matters for learning to take place in education. The last category that students and teachers came up with suggestions belonged to the exam dimension of the EPP, particularly, the picture description part in the speaking exam. There was a criticism regarding the selection of the appropriate pictures to describe in the speaking exam as some pictures were found to be too abstract and difficult for students. This criticism should be dealt with utmost attention as the aim of using visuals is to 
encourage students to generate ideas and help them produce more language by activating their background knowledge. However, if the pictures became a source of impediment rather than a visual aid, then there would be no point in integrating them as part of the assessment. This might lead to students' being discouraged from producing language due to the difficulty of the task.

\section{Conclusion}

Overall, the present study tried to investigate students' and teachers' perspectives of an English Preparatory program offered at a foundation university in Turkey. Considering the participants' perspectives, we can conclude that EPP achieved success in relation to homework assignments, exams, overall program and performance assessment while it needs to be improved regarding extra-curricular activities and online programs. However, before taking any further action for the improvement of the weak dimensions, it might be better to hold a comprehensive needs-analysis survey at the beginning of the academic year and identify the particular needs of all stakeholders. It might also be better to do program evaluation at regular intervals rather than doing it at the end of learning. This way, we believe that it would be easier to take immediate actions for some of the issues that may not be favorable or impede learning. In addition, we suggest that quantitative data collection tools could be supported by qualitative tools in order to reach deeper information and more supportive data from the research participants.

\section{References}

Akpur, U. (2017). Yıldız Teknik Üniversitesi hazırlık öğretim programının değerlendirilmesi. Cumhuriyet Uluslararası Ĕ̈itim Dergisi, 6(4), 441-457.

Arap, B. (2016). An investigation into the implementation of English preparatory programs at tertiary level in Turkey. (Doktora Tezi). Çukurova Üniversitesi, Adana.

Bandura, A. (1986). Social foundations of thought and action: A social cognitive theory. Englewood Cliffs, NJ: Prentice Hall.

Brown, H. D. (2007). Teaching by principles: An interactive approach to language pedagogy ( $\left.3^{\text {rd }} \mathrm{ed}.\right)$. New York: Longman.

Brown, S. (2005) Assessment for Learning. Learning and Teaching in Higher Education, (1), 81-89.

Coşkun, A. (2013). An investigation of the effectiveness of the modular general English language teaching preparatory program at a Turkish university. South African Journal of Education, 33(3).

Creswell, J. W., \& Plano Clark, V. L. (2011). Designing and conducting mixed methods research $\left(2^{\text {nd }}\right.$ ed.). Thousand Oaks, CA: Sage.

Çelik-Yazıcı, İ., \& Kahyalar, E. (2018). Evaluation of the preparatory program at Çukurova University: Focus on the content, the teaching-learning process and the assessment system. International Journal of Languages' Education and Teaching, 6(1), 231-240.

Erarslan, A , \& Zehir Topkaya, E . (2017). EFL students attitudes towards e-learning and effect of an online course on students success in English. The Literacy Trek, 3(2), 80-101. Retrieved on July 28, 2018 from http://dergipark.gov.tr/literacytrek/issue/32167/350186

Flowerdew, J., \& Peacock, M. (2001). (Eds.). Research perspectives on English for academic purposes. Cambridge: Cambridge University Press. 
Fraenkel, J. R., Wallen, N.E., \& Hyun, H. H. (2012). How to design and evaluate research in education ( $8^{\text {th }}$ ed.). New York: Mc Graw Hill.

Gardner, M., Roth, J., \& Brooks-Gunn, 1. (2008). Adolescents' participation in organized activities and developmental success 2 and 8 years after high school: Do sponsorship, duration, and intensity matter? Developmental Psychology, 44(3), 814-830.

Goldsmith, J. (2009). Pacing and time allocation at the micro- and meso-level within the class hour: Why pacing is important, how to study it, and what it implies for individual lesson planning. Journal of Teaching \& Learning Language \& Literature, 1(1), 30-48.

İnal, B., \& Aksoy, E. (2014). Çankaya Üniversitesi hazırlık sınıfı, İngilizce hazırlık öğretim programının değerlendirilmesi. Eğitim ve Öğretim Araştırmaları Dergisi, 3(3), 85-98.

Kirkpatrick, T. A. (2011). Internationalization or Englishization? Medium of instruction in today's Universities. Center for Governance and Citizenship. The Hong Kong Institute of Education. Working Paper Series No. 2011 / 003.

Owen, J. M. (2007). Program evaluation: Forms and approaches ( $3^{\text {rd }}$ ed.). New York: The Guilford Press.

Öner, G., \& Mede, E. (2015). Evaluation of A1 level program at an English preparatory school in a Turkish university: A case study. International Association of Research in Foreign Language Education and Applied Linguistics ELT Research Journal, 4(3), 204-226.

Özdoruk-Höke, P. (2016). Evaluation of the English Language preparatory school curriculum at Yıldırım Beyazıt University. (Yüksek Lisans Tezi). Orta Doğu Teknik Üniversitesi, Ankara.

Richards, J. C. (2001). Curriculum development in language teaching. UK: Cambridge University Press.

Royse, D., Thyer, B. A., \& Padgett, D. K. (2010). Program evaluation: An introduction. Belmont, CA: Wadsworth Cengage Learning.

Sanders, J. R., \& Sullins, C. D. (2006). Evaluating school programs: An educator's guide. Thousand Oaks: Corwin Press.

Strauss, A., \& Corbin, J. (1998) Basics of qualitative research: grounded theory procedures and techniques. Sage, Newbury Park, California.

TEPAV (2013). Turkey national needs assessment of state school English language teaching. Ankara: Mattek Matbaacilik.

TEPAV. (2015). Türkiye'de yükseköğretim kurumlarındaki ingilizce eğitimi. Bir durum analizi, Ankara: Tasarım ve Baskı Yayıncılık.

Weir, C. J., \& Roberts, J. (1994). Evaluation in ELT. Oxford: Blackwell. 


\section{Türkiye'de bir vakıf üniversitesinin İngilizce hazırlık programının değerlendirilmesi}

\section{$\ddot{O} z$}

Bu karma yöntem çalışmanın amacı 2017-18 akademik yılında Türkiye'de İngilizce eğitim veren bir vakıf üniversitesinde uygulanan İngilizce Hazırlık Programının güçlü ve zayıf yönlerinin açığa çıkarılmasıdır. Çalışmaya hazırlık programında eğitim gören 241 öğrenci ve 26 öğretmen katılmıştır. Veriler araştırmacılar tarafından geliştirilen "Program Değerlendirme Anketi" ve odak grup görüşmesi yoluyla toplanmıştır. Çalışma sonuçları İngilizce Hazırlık Programının güçlü yönlerinin ödevler, sınavlar ve program olduğunu, zayıf yönlerinin ise program dışı etkinlikler ve çevrim içi programlar olduğunu ortaya çıkarmıştır. Araştırmanın sonuçları ayrıca programa yönelik öğretmen ve öğrenci görüşlerinin birbirinden anlamlı şekilde farklılaştığını da ortaya koymuştur. Son olarak, öğretmen ve öğrenciler programın hızında, ders kitabı ve çalışma kitaplarında, portfolyo ödevlerinde ve konuşma sınavında kullanılan fotoğraflarda iyileștirmeler yapılması gerektiğini belirtmişlerdir. Çalışmanın bulgularının var olan programın iyileştirilmesine ve daha etkili öğrenme ortamlarının hayata geçirilmesine katı sağlayacağı düşünülmektedir.

Anahtar Sözcükler: Program değerlendirme; İngilizce hazırlık programı; öğrenci ve öğretmen görüşleri

\section{AUTHOR BIODATA}

İlknur Bayram currently works as a curriculum and instruction specialist at the Center for Teaching and Learning, TED University and has a PhD in Curriculum Development. Her research interests are teacher professional development, lesson study, curriculum development and evaluation.

Özlem Canaran currently works as the head of the department of foreign languages at UTAA. She has a PhD in ELT. Her research interests are team teaching, continuous professional development and curriculum development. 